\title{
Seasonal changes in plasma concentrations of gonadotropins and in the responsiveness of the pituitary and testis to GnRH in a desert rodent, the sand rat (Psammomys obesus)
}

\author{
F Khammar, R Brudieux * \\ Université (USTHB) d'Alger, Laboratoire d'Endocrinologie et Écophysiologie Animale, \\ Unité de Recherches sur les Zones Arides, BP 119, rue Danton, Alger, Algérie
}

(Received 6 June 1990; accepted 9 September 1991)

\begin{abstract}
Summary - The male sand rat (Psammomys obesus), captured alive in the Sahara desert in the area of Béni-Abbès (Algeria), exhibited seasonal changes in plasma concentrations of $L H$, characterized by an increase in early summer. Administration of a standard dose of $\mathrm{GnRH}(200 \mathrm{ng} / 100 \mathrm{~g}$ body weight) failed to elicit significant season-dependent changes in $\mathrm{LH}$ release, whereas the increase in plasma testosterone was maximum in June-July and quite small between November and March-April. The present results suggest that the summer seasonal onset of the testicular endocrine activity of the sand rat is due to increases both in LH release and in testis sensitivity to gonadotropin.
\end{abstract}

sand rat (Psammomys obesus)/ seasonal changes / pituitary-testicular axis / gonadotropins / GnRH

Résumé - Variations saisonnières de la concentration plasmatique en gonadotrophines et de la réponse à GnRH de l'hypophyse et du testicule d'un rongeur désertique, le rat des sables (Psammomys obesus). Le rat des sables (Psammomys obesus), capturé dans son biotope naturel du désert saharien, dans la région de Béni-Abbès (Algérie), présente des variations saisonnières de sa concentration plasmatique en $\mathrm{LH}$, caractérisées par une augmentation au début de l'été. L'administration intraveineuse de GnRH (200 ng/100 g de poids corporel) ne provoque pas de variations annuelles significatives de la sécrétion de LH; par contre, cette dose de GnRH induit des variations saisonnières de la concentration plasmatique en testostérone, qui est maximale en juinjuillet et très faible entre novembre et mars-avril. Ces résultats suggèrent que la reprise saisonnière estivale de l'activité endocrine du testicule du rat des sables est due à une augmentation de la sécrétion de LH et à un accroissement de la sensibilité testiculaire à cette gonadotrophine.

rat des sables (Psammomys obesus) / variation saisonnière / axe hypophyso-testiculaire / gonadotrophines / GnRH

\footnotetext{
* Correspondence and reprints

Present address: Laboratoire d'Endocrinologie Comparée, UFR de Biologie, Université de Bordeaux I, Avenue des Facultés, 33405 Talence-Cedex, France
} 


\section{INTRODUCTION}

The wild sand rat (Psammomys obesus) in the Béni Abbès area of the Sahara desert, is a seasonal breeder; its endocrine testicular activity exhibits a marked annual cycle, characterized by a rise in early summer (June-July), a maximum in autumnwinter and a decrease throughout the spring (Khammar and Brudieux, 1984).

To elucidate the neuroendocrine mechanisms which control these variations of testicular endocrine function, we have previously shown the occurrence of annual changes in the sensitivity to $\mathrm{LH}$ of the sand rat testis, mainly characterized by a marked increase in early summer (Khammar and Brudieux, 1989).

The objectives of this study were to investigate the annual pattern of gonadotropin secretion and the pituitary and testicular responsiveness to exogenous administration of $\mathrm{GnRH}$ in order to determine whether the putative seasonal variation in $\mathrm{LH}$ release results from annual changes in pituitary sensitivity to $\mathrm{GnRH}$, and if there is an annual pattern of testicular sensitivity to an endogenous concentration of $\mathrm{LH}$.

\section{MATERIALS AND METHODS}

\section{Animals:}

Adult male sand rats (Psammomys obesus) were captured alive in the Béni-Abbès area of Algeria $\left(30^{\circ} 7^{\prime} \mathrm{N}, 2^{\circ} 10^{\prime} \mathrm{W}\right)$, in the Sahara desert. Maturity was checked according to previously described criteria (Amirat et al, 1980). Immediately after trapping, they were kept for 12-24 $\mathrm{h}$ in individual cages in the Laboratory and exclu- sively fed fresh plants (Suaeda mollis) ad libitum. All experiments were carried out between 9.00 and $13.00 \mathrm{~h}$. Blood samples were immediately centrifuged and plasma stored at $-25^{\circ} \mathrm{C}$ until hormone assays were performed. After decapitation, testes and seminal vesicles were quickly removed and weighed.

\section{Experiment 1 : plasma $L H$ and FSH concentrations}

Ninety-six adult male sand rats were caught between June 1984 and December 1985 (ie 1984, June and October, then 1985, January, late February, late March, June, July, November and December). They were killed by decapitation. Blood from the neck was collected on calcium heparinate at $0-5^{\circ} \mathrm{C}$.

\section{Experiment 2 : pituitary and testes response to $\mathrm{GnRH}$ administration}

Sixty-one adult male sand rats were caught between March 1984 and December 1985 (ie 1984, March, June and November, then 1985, late March, June, November and December). They were anaesthetized with an intraperitoneal injection of $4 \mathrm{mg}$ pentobarbitone sodium $/ 100 \mathrm{~g}$ body wt (Nembutal, Abott, St Rémi-sur-Avre, France). The left carotid artery and right jugular vein were catheterized. Animals were heparinized with an iv administration of 50 iu $(0.2 \mathrm{ml})$ calcium heparinate $/ 100 \mathrm{~g}$ body wt. Then $200 \mathrm{ng}$ $\mathrm{GnRH} / 100 \mathrm{~g}$ body wt (Stimu-LH-synthetic decapeptide, Laboratoires Roussel, France) dissolved in $0.2 \mathrm{ml} 0.9 \%(\mathrm{~W} / \mathrm{v}) \mathrm{NaCl}$ containing $0.2 \%$ BSA were injected through the jugular vein. Blood samples $(4 \times 1 \mathrm{ml})$ were withdrawn from the carotid artery catheter before $(0 \mathrm{~min})$ and 15,60 and 90 min after GnRH administration, in order to evaluate the basal plasma levels of $\mathrm{LH}$ and testosterone, $\mathrm{LH}$ response to GnRH (15 $\mathrm{min}$ ) and testosterone response to endogenous LH (60 and $90 \mathrm{~min}$ ). In preliminary experiments we checked that, 15 min following GnRH administration, the secretion of $\mathrm{LH}$ was already 
maximum. All the animals were then killed by decapitation.

\section{Hormone assays}

Plasma $\mathrm{LH}$ and $\mathrm{FSH}$ were measured by heterologous radioimmunoassays. The LH reference standard (rat LH-RP2) was a gift from the $\mathrm{Na}$ tional Institute of Arthritis, Metabolism and Digestive Diseases (NIAMDD, Bethesda, MA, USA). LH (rat LH SX1-1, donated by Dr Justiz, Gif-sur-Yvette, France) was routinely iodinated according to the chloramine T method (Greenwood et al, 1963) and immediately purified on a Sephadex G-50 column. The antibodies used were anti-rat LH SX1-1 supplied by Dr Dubois (INRA, France). A double antibody procedure was used to separate bound from free hormones. The method was validated by ViguierMartinez (1983). The detection limit of the LH assay was $0.62 \mathrm{ng} / \mathrm{ml}$; intra- and inter-assay coefficients of variation were 14 and $8 \%$, respectively. Plasma FSH concentrations were measured using the RIA rat FSH kit of the NIAMDD. The limit of detection of the FSH assay was $90 \mathrm{ng} / \mathrm{ml}$. The intra-assay coefficient of variation was $10 \%$. Plasma LH and FSH levels in the sand rat were expressed as NIAMDD LH-RP2 and FSH-RP1 reference standards.

Testosterone concentrations in plasma aliquots were measured after extraction by ethylacetate-cyclohexane and purification on celite columns, according to the radioimmunoassay method validated by Darbeida and Brudieux (1980). Because of the very low plasma values at $0 \mathrm{~min}$, the purification on celite column was omitted (Khammar and Brudieux, 1987). We checked that results obtained from assays of the same sample, with and without the purification step, were not statistically different.

\section{Statistical analysis}

Means and standard errors (SEM) were calculated and the statistical significance of the results was determined by Student's $t$-test.

\section{RESULTS}

\section{Seasonal changes in plasma gonadotropin concentrations (Exp 1)}

\section{Testis and seminal vesicles weights (table I)}

The weights of testis and seminal vesicles of the sand rats exhibited seasonal variations. In late March 1985, they were still high in 7 animals and low in 4 others. Levels were low in all animals in June 1985. Testicular and seminal vesicles weights were increased for $2 / 6$ sand rats in June 1984 and for all the animals in July 1985. They were highest in October 1984 and in November-December 1985. Because of individual variations, the sand rats trapped in late March 1985 and in June 1984 were separated into 2 groups according to seminal vesical weights (tables I, II).

\section{Plasma LH concentrations (table I)}

Mean values ranged from $2.7-9.8 \mathrm{ng} / \mathrm{ml}$. $\mathrm{LH}$ plasma concentrations were high in all the sand rats trapped in June 1984; they decreased in October $(-76 \% ; P<0.01)$ and remained low until late March 1985, at least in animals which still had large testes and seminal vesicles. A significant increase occurred in June $1985(+120 \%$; $P<0.001$, compared to late March) and continued in July 1985. Such an increase could already be observed in late March 1985, despite individual variations in the 4 animals with low testicular and seminal vesicular weights. As in 1984, LH plasma concentrations declined in autumn 1985 $(-54 \% ; P<0.001$, compared to June 1985). 
Table I. Seasonal changes in testis and seminal vesicle weights and in plasma concentrations of FSH and LH in adult male sand rat (Psammomys obesus).

\begin{tabular}{|c|c|c|c|c|c|}
\hline $\begin{array}{l}\text { Time of } \\
\text { sample }\end{array}$ & $\begin{array}{l}\text { No } \\
\text { of } \\
\text { animals }\end{array}$ & $\begin{array}{l}\text { Left testis } \\
\text { weight } \\
\text { (mg) }\end{array}$ & $\begin{array}{l}\text { Seminal } \\
\text { vesicle } \\
\text { weight } \\
(\mathrm{mg})\end{array}$ & $\begin{array}{l}\text { Plasma FSH } \\
\text { (ng NIAMDD- } \\
\text { rat FSH-RP, } \\
(m /)\end{array}$ & $\begin{array}{l}\text { Plasma } L H \\
\text { (ng NIAMDD- } \\
\text { rat } L H-R P_{2} \\
/ m l)\end{array}$ \\
\hline \multirow[t]{2}{*}{ Jun 84} & 2 & $175 \pm 26$ & $189 \pm 40$ & 111 & 6.4 \\
\hline & $\begin{array}{l}4 \\
(6)\end{array}$ & $\begin{array}{c}124 \pm 15 \\
(131 \pm 9)\end{array}$ & $\begin{array}{c}64 \pm 6 \\
(81 \pm 4)\end{array}$ & $\begin{array}{c}114 \pm 3 \\
(113 \pm 2)\end{array}$ & $\begin{array}{c}7.9 \pm 0.6 \\
(7.6 \pm 0.5)\end{array}$ \\
\hline Oct 84 & 7 & $241 \pm 19$ & $196 \pm 28$ & $151 \pm 15$ & $2.7 \pm 0.8$ \\
\hline Jan 85 & 10 & $229 \pm 28$ & $436 \pm 51$ & $130 \pm 9$ & $4.7 \pm 1.1$ \\
\hline End Feb 85 & 7 & $299 \pm 15$ & $277 \pm 49$ & - & $3.5 \pm 1.0$ \\
\hline \multirow[t]{2}{*}{ End Mar 85} & 7 & $230 \pm 25$ & $187 \pm 7$ & $109 \pm 8$ & $2.8 \pm 0.7$ \\
\hline & $\begin{array}{l}4 \\
(11)\end{array}$ & $\begin{array}{c}144 \pm 27 \\
(199 \pm 22)\end{array}$ & $\begin{array}{c}64 \pm 5 \\
(142 \pm 20)\end{array}$ & $\begin{array}{r}125 \pm 19 \\
(115 \pm 8)\end{array}$ & $\begin{array}{c}7.6 \pm 2.7 \\
(4.2 \pm 1.1)\end{array}$ \\
\hline Jun 85 & 23 & $154 \pm 10$ & $63 \pm 9$ & $132 \pm 11$ & $7.7 \pm 0.6$ \\
\hline Jul 85 & 5 & $186 \pm 16$ & $199 \pm 22$ & $109 \pm 5$ & $9.8 \pm 1.2$ \\
\hline Nov 85 & 9 & $304 \pm 15$ & $228 \pm 15$ & $112 \pm 5$ & $4.5 \pm 0.9$ \\
\hline Dec 85 & 18 & $297 \pm 15$ & $194 \pm 13$ & $126 \pm 16$ & $4.9 \pm 0.5$ \\
\hline
\end{tabular}

Values are means $\pm S E M$.

In June 1984 and in late March 1985, numbers in parentheses are relative to all the animals caught.

\section{Plasma FSH concentrations (table I)}

Mean values did not show significant variations throughout the year; they ranged from $109 \pm 5-151 \pm 15 \mathrm{ng} / \mathrm{ml}$.

\section{Release of $\mathrm{LH}$ and testosterone in response to GnRH (Exp 2)}

Sand rats used in this experiment also exhibited an annual pattern in testicular and seminal vesicular weights (table II). They were high in all the animals trapped in March 1984 and low in 4/9 caught in March 1985. They remained low for all the animals in June 1985, whereas they increased as early as June 1984; in autumn 1984 and 1985, testicular and seminal vesicles sizes were greatest.
After $15 \mathrm{~min}$, administration of $200 \mathrm{ng}$ $\mathrm{GnRH} / 100 \mathrm{~g}$ body wt induced modest increases in plasma LH concentrations, of only a few $\mathrm{ng} / \mathrm{ml}$ (table II). Annual variation in plasma LH levels measured $15 \mathrm{~min}$ following $\mathrm{GnRH}$ administration was not statistically significant. So there was no seasonal change in plasma LH response to exogenous $\mathrm{GnRH}$.

Basal plasma concentrations of testosterone were low; they ranged from $0.15 \pm$ $0.02 \mathrm{ng} / \mathrm{ml}$ to $0.29 \pm 0.07 \mathrm{ng} / \mathrm{ml}$. A seasonal variation was observed with a minimum in June and a maximum in November (June 1985 versus November 1984 : 48\%; $P<0.05$ ).

Administration of $200 \mathrm{ng} \mathrm{GnRH/100} \mathrm{g}$ body wt increased testosterone release. However, the testis response changed with the season (table II): $60 \mathrm{~min}$ after GnRH 


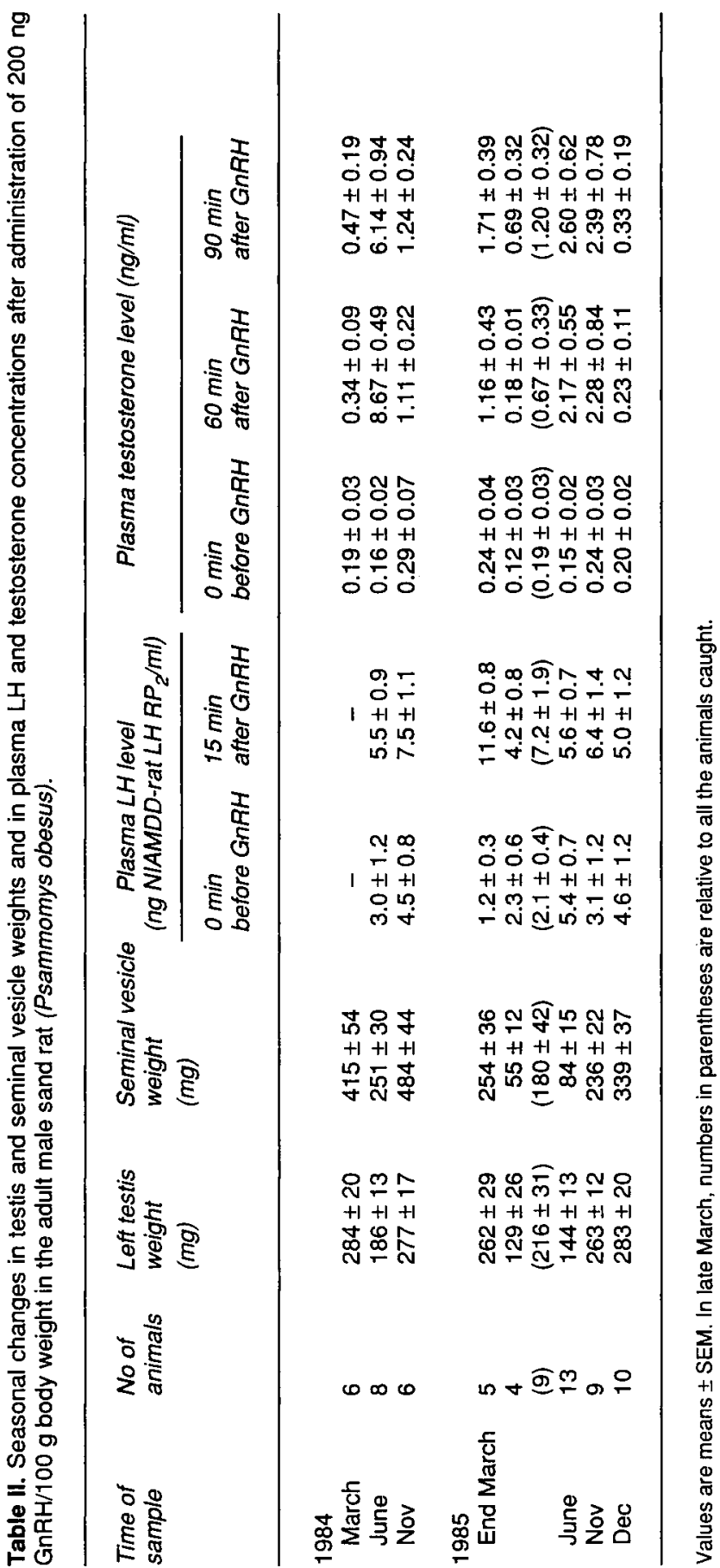


administration, plasma concentration of testosterone increased more in June than at other periods. At 90 min after $\mathrm{GnRH}$ administration, plasma testosterone concentration changes followed a similar pattern (table II).

\section{DISCUSSION}

The weights of testes and seminal vesicles of the sand rats used in the present experiments exhibited seasonal variations similar to those previously reported (Khammar and Brudieux, 1984).

We have shown that the sand rat (Psammomys obesus), captured alive in the field in the Sahara desert, exhibited seasonal variation in plasma concentration of $\mathrm{LH}$, mainly characterized by an increase in early summer (June-July). These data are the first dealing with annual changes in the pituitary gonadotrophic activity in a desert rodent. Fluctuations in LH secretion have been reported in domestic animals (pigmy goat: Muduuli et al, 1979; ram: Schanbacher and Lunstra, 1976; Ortavant and Loir, 1980) and in wild animals (vole: Charlton et al, 1983; mongoose: Soares and Holfmann, 1981; squirrel: Barnes, 1986; fox and badger: Maurel, 1981; Audy et al, 1985; deer: Lincoln and Kay, 1979; Bubenik et al, 1982). In most cases, seasonal changes in plasma LH levels parallelled those of plasma testosterone concentrations.

In the sand rat, seasonal profiles of pituitary and testis activities were opposite: whereas production of testosterone and seminal vesicles weights were maximum, plasma concentrations of $\mathrm{LH}$ were the lowest in winter. Moreover, at the end of March, plasma LH levels in animals with regressed genital apparatus were higher than in those with large testes and seminal vesicles. In spring the testicular endocrine activity decreased until it was at a minimum in June, whilst plasma LH concentrations increased to a maximum in early summer. Thus, our data suggest that seasonal variations in LH secretion by the pituitary of the sand rat are closely related to those of the feedback inhibition by gonadal androgens; the decline in androgen production during spring, decreasing the negative feedback, might allow increased LH secretion.

It is noteworthy that the sand rat exhibited seasonal changes in $\mathrm{LH}$ secretion although inhabiting low latitudes. The influence of environmental factors such as temperature, nutrition and photoperiod needs to be examined. Their annual variations in the Béni-Abbès area have been previously described (Khammar and Brudieux, 1984). The implication of photoperiod is most likely because of the onset of pituitary activity took place after the summer solstice and the photoperiodic regulation of neuroendocrine gonadal activity is well known (Turek and Campbell, 1979); although the involvement of photoperiod decreases when latitude decreases, nevertheless only a few hours annual variation in daylength are sufficient to control breeding activity.

However, due to the infrequent trapping periods, and although it is not possible to accurately determine the duration of the seasonal patterns of pituitary and testicular activities, a time-lag obviously occurred: in June July the incremental plasma concentration of LH was already large whereas an increase in testicular function had only just begun. In species in which it has been previously reported (ram: Schanbacher and Lunstra, 1976; Ortavant and Loir, 1980; pigmy goat: Muduuli et al, 1979; fox and badger: Maurel, 1981; Audy et al, 1985), such a time-interval is seen as an argu- 
ment for the involvement of $\mathrm{LH}$ in the seasonal recrudescence of testicular endocrine activity.

In our experimental conditions, $15 \mathrm{~min}$ after administration of $200 \mathrm{ng} \mathrm{GnRH} / 100 \mathrm{~g}$ body wt, plasma LH concentration increased only slightly and there was no significant seasonal change in the pituitary response. This is in disagreement with data on the ram (Lincoln, 1977), the deer (Lincoln and Kay, 1979; Plotka et al, 1984; Van Mourik et al, 1986) and the mongoose (Soares and Hoffmann, 1982), which showed that the amplitude and/or the duration of the response of the pituitary to $\mathrm{GnRH}$ were the greatest just before and/or during the period of maximum testicular activity. Nevertheless, in order to determine the factors which trigger seasonal variations in LH secretion, annual changes in $\mathrm{GnRH}$ release from the hypothalamus under basal conditions and in response to a standard dose of testosterone could be checked.

Our results show that the seasonal onset of the testicular endocrine activity of the sand rat was preceded by an increase in pituitary LH secretion both in June and July and, as previously reported, by an increase in testicular sensitivity to $\mathrm{LH}$ (Khammar and Brudieux, 1989). The present results on release of testosterone in response to $\mathrm{GnRH}$ strengthen the above conclusion. This is in spite of a lower plasma level of endogenous gonadotropin after $\mathrm{GnRH}$ treatment in the present experiment, as compared to that induced by exogenous administration of 25 iu hCG (Khammar and Brudieux, 1989). In early summer, this endogenous LH was sufficient to elicit a maximum plasma testosterone concentration increase. This agrees with a higher testis sensitivity to $\mathrm{LH}$ at this time. Moreover, from November to late March, whereas the testis response following hCG administration was markedly re- duced but still significant compared to June-July, it was quite small after $\mathrm{GnRH}$ treatment.

In conclusion, the present results clearly show that the seasonal recrudescence of the testicular endocrine activity of the sand rat captured in its desert environment is due to a summertime increase both in $\mathrm{LH}$ release and in testis sensitivity to $\mathrm{LH}$. These factors are unlikely to be involved in the spring decline in testicular function and a putative role of thyroid hormones (Bois$\sin$ et $a l, 1980$ ) is currently being investigated.

\section{ACKNOWLEDGMENTS}

The authors gratefully acknowledge the assistance of Drs MC Martinez, M Blanc and JC Poirier in the $\mathrm{LH}$ and $\mathrm{FSH}$ radioimmunoassay. Rat $\mathrm{LH}$ for iodination, anti-rat $\mathrm{LH}$ and anti-rat FSH + rat $\mathrm{FSH}$ for iodination + LH and FSH reference standards were supplied respectively by $\mathrm{Dr}$ Justisz, Dr Dubois and the NIAMDD (Dr Parlow). They also wish to thank Dr JP Gosling (University College of Galway, Ireland) for correction of the manuscript.

\section{REFERENCES}

Amirat Z, Khammar F, Brudieux R (1980) Seasonal changes in plasma and adrenal concentrations of cortisol, corticosterone, aldosterone and electrolytes in the adulte male sand rat (Psammomys obesus). Gen Comp Endocrinol 40, 36-43

Audy MC, Bonnin M, Souloumiac J, Ribes C, Kerdelhue B, Mondain-Monval M, Scholler R, Canivenc $R$ (1985) Seasonal variations in plasma luteinizing-hormone and testosterone levels in the European badger, Meles meles L. Gen Comp Endocrinol 57, 445-453

Barnes BM (1986) Annual cycles of gonadotropins and androgens in the hibernating golden-mantled ground squirrel. Gen Comp Endocrinol $62,13-22$ 
Boissin J, Jallageas M, Assenmacher I (1980) Cycle annuel du fonctionnement testiculaire des oiseaux et des mammifères. Régulation par les facteurs de l'environnement et influence des interrelations testo-thyroïdiennes. In: Rythmes et Reproduction (R Ortavant, A Reinberg, eds) Masson, Paris, 141-155

Bubenik GA, Morris JM, Schams D, Claus A (1982) Photoperiodicity and the circannual levels of LH, FSH and testosterone in normal and castrated male white tailed-deer. Can J Physiol Pharmacol 60, 788-793

Charlton HM, Chiappa SA, Fink G, Grocock CA, Versi $E$ (1983) Hypothalamic gonadotropinreleasing hormone and pituitary luteinizing hormone contents in the male vole (Microtus agrestis) in the field during the breeding and non-breeding seasons. Can $J$ Zool 61, 24052410

Darbeida H, Brudieux R (1980) Seasonal variations in plasma testosterone and dihydrotestestosterone levels and in metabolic clearance rate of testosterone in rams in Algeria. $J$ Reprod Fertil 59, 229-235

Greenwood FC, Hunter WM, Glover JS (1963) The preparation of 131/-labelled human growth hormone of high specific radioactivity. Biochem J 89, 114-123

Khammar F, Brudieux R (1984) Seasonal changes in testicular contents of testosterone and androstenedione and in the metabolic clearance rate of testosterone in the sand rat (Psammomys obesus). J Reprod Fertil 71, 235-241

Khammar F, Brudieux R (1987) Seasonal changes in testicular contents and plasma concentrations of androgens in the desert gerbil (Gerbillus gerbillus). J Reprod Fertil 80, 589-594

Khammar F, Brudieux R (1989) Seasonal changes in plasma testosterone concentrations in response to administration of hCG, in a desert rodent, the sand rat (Psammomys obesus). J Reprod Fertil 85, 171-175

Lincoln GA (1977) Changes in pituitary responsiveness to luteinizing hormone releasing hormone in rams exposed to artificial photoperiods. J Endocrinol 73, 519-527

Lincoln GA, Kay RNB (1979) Effects of season on the secretion of $\mathrm{LH}$ and testosterone in in- tact and castrated red deer stags (Cervus e/aphus). J Reprod Fertil 55, 75-80

Maurel D (1981) Variations saisonnières des fonctions testiculaire et thyroïdienne en relation avec l'utilisation de l'espace et du temps chez le blaireau européen (Meles meles $L$ ) et le renard roux (Vulpes vulpes L). Thèse Doct ès Sciences, Université de Montpellier, 302 pp

Muduuli DS, Sanford LM, Palmer WM, Howland BE (1979) Secretory patterns and circadian and seasonal changes in luteinizing hormone, follicle stimulating hormone, prolactin and testosterone in the male pygmy goat. $J$ Anim Sci 49, 543-553

Ortavant R, Loir M (1980) Photopériodisme et reproduction. In : Rythmes et Reproduction (R Ortavant, A Reinberg, eds) Masson, Paris, 157-169

Plotka ED, Seal US, Letellier MA, Verme LJ, Ozoga JJ (1984) Early effects of pinealectomy on $\mathrm{LH}$ and testosterone secretion in white-tailed deer. J Endocrinol 103, 1-7

Schanbacher BD, Lunstra DD (1976) Seasonal changes in sexual activity and serum levels of LH and testosterone in Finnish Landrace and Suffolk rams. J Anim Sci 43, 644-650

Soares MJ, Hoffmann JC (1981) Seasonal reproduction in the mongoose, Herpestes auropunctatus. I. Androgen, luteinizing hormone and follicle stimulating hormone in the male. Gen Comp Endocrinol 44, 350-358

Soares MJ, Hoffmann JC (1982) Seasonal reproduction in the mongoose, Herpestes auropunctatus. III. Regulation of gonadotropin secretion in the male. Gen Comp Endocrinol 47, 235-242

Turek FW, Campbell CS (1979) Photoperiodic regulation of neuroendocrine gonadal activity. Biol Reprod 20, 32-50

Van Mourik S, Stelmasiak T, Outch KH (1986) Seasonal variation in plasma testosterone, luteinizing hormone concentrations and $\mathrm{LH}-$ $\mathrm{RH}$ responsiveness in mature male rusa deer (Cervus rusa timorensis). Comp Biochem Physiol 83A, 347-351

Viguier-Martinez MC (1983) Étude des mécanismes de rétroaction testiculaire sur le complexe hypothalamo-hypophysaire chez le rat mâle. Thèse Doct ès Sciences, Université de Tours, $125 \mathrm{pp}$ 